\title{
Social Presence Antecedents and Consequences in Massive Open Online Courses
}

\author{
Jehad Imlawi ${ }^{1}$ \\ ${ }^{1}$ IS Department, Faculty of Information Technology, Al Al-Bayt University, Mafraq, Jordan \\ Correspondence: Jehad Imlawi, IS Department, Faculty of Information Technology, Al Al-Bayt University, \\ Mafraq, Jordan.
}

Received: January 24, 2018

Accepted: February 17, 2018

Online Published: February 23, 2018

doi:10.5539/ibr.v11n4p32

URL: https://doi.org/10.5539/ibr.v11n4p32

\begin{abstract}
A massive open online course (MOOC) is an emerging online courses platform that solicited a massive participation, because it is accessible through the Internet. Students, who seek open courses in MOOCs, are influenced by the degree of social presence they perceive when interacting in such online learning communities. The online community design artifacts, that promote social presence in MOOCs websites, are critical to foster online students' behavior.

This study aimed to investigate a thorough list of online community design artifacts that could influence social presence perception in MOOCs websites. The list included categories related to the MOOCs instructor, students, and the MOOCs website. The study also investigates the impact of social presence on students' behavior; satisfaction, enjoyment, and their attitude toward the website.

To validate the research model, an online survey was utilized. Results indicated that the model explained a great share of the variance for the social presence.
\end{abstract}

Keywords: social presence, MOOCs, learning enjoyment, student satisfaction, attitude toward a website

\section{Introduction}

MOOCs are classes that are available online, and open for diverse learners with different backgrounds (Breslow et al., 2013). MOOCs are transforming higher education; Voss (2013) argued that MOOCs attract a larger audience than any other form of online education. It attracts learners who speak different languages, with a wide range of ages and prior education. However, there has been limited research investigated how different MOOCs platforms could influence learners' satisfaction, their enjoyment, and their attitude toward these MOOCs platforms.

Social presence is defined by Short, Williams, and Christie $(1976$, p. 65) as "the degree of salience of the other person in the interaction and the consequent salience of the interpersonal relationships". Substantial research investigated social presence, and its influence on online user behavior. Most prior research has confirmed the positive impact of social presence on factors such as trust (Hess, Fuller, and Campbell, 2009), information sharing (Miranda \& Saunders, 2003), and attitude toward websites (Daliri, Rezaei, and Ismail, 2014). However, little research were conducted on social presence in the field of MOOCs.

Social presence is related to Face-to-Face education, where students directly interact with instructor and other fellow students (Adams, Morris, \& Scotter, 1999). Online education, such as MOOCs, have less degree of social presence (Imlawi and Gregg, 2014). Imlawi, Gregg, and Karimi (2015) argued that what is true in face-to-face environments might not be true in online environments. Thus, more research is still needed to improve our understanding of how to improve social presence in MOOCs websites.

In online communities, like MOOCs, social presence emerges as one of the most important design principles (Biocc, Kim, \& Levy, 1995) that significantly influence online users' behavior. Thus, research is needed to gain insight into the design of MOOCs, and to improve MOOCs websites in a way that improve user behavior and improve users' attitude toward the MOOCs websites (Shen, and Khalifa, 2009). Moreover, little research has been conducted to define online community artifacts that could influence social presence in online environments (Kumar \& Benbasat, 2006). Qiu and Benbasat (2005) argued that it would be valuable to invest more research on the impact of online community artifacts on social presence. 
Prior research has thoroughly studied social presence. However, there still some gaps in research on social presence. First, little research investigated social presence in fully online asynchronous courses (Rodriguez, 2015). Second, most research has focused on the influence of social presence on online user behavior, with less research focused on the antecedents of social presence.

This research tried to examine the online community artifacts that could influence social presence. Accordingly, three categories of these artifacts were identified in this research. First category includes factors related to the course instructor, self-presentation and extraversion. Second category includes factors related to the MOOC students, attention, perceived control over a MOOC website, perceived responsiveness of a MOOC website, and perceived synchronicity of a MOOC website. Third category includes one factor related to the MOOC website itself, media richness.

The goal of this study is to address gaps in the literature, by investigating the key antecedents and consequences of social presence in MOOCs websites. This study contributes to research by investigating a wide variety of online community artifacts and its impact on social presence. The research also study the impact of social presence on online user behavior; satisfaction, enjoyment, and attitude toward MOOCs websites.

\section{Literature Review}

\subsection{Social Presence}

Short et al. (1976) investigated social presence, they define it as "the degree of salience of the other person in the interaction and the consequent salience of the interpersonal relationships" (Short et al., 1976, p. 65). They emphasized on the importance of social presence in communication media. Social presence is related to the feeling of warmth when interacting with others. It was found to be the highest in face-to-face interactions, thus, online interactions are required to convey personal, warm, sociable, and sensitive feelings to substitute for social presence (Shen \& Khalifa, 2009). Social presence is one of the central design principles for social computing technologies such as Email, online chat, and online communities (Shen \& Khalifa, 2009; Riva, Davide, and IJsselsteijn, 2003).

Online learning has thrived in the last decade because of the explosive development in interpersonal communication. Communication is a cornerstone in online learning, because of the physical separation between the learners and the learning providers. However, Ward \& Newlands (1998) argued that online learning environment is not as effective as face-to-face learning environment because of the lack of a direct interaction. Bullen (2007) found that course students who utilized computer-mediated conferencing felt disconnected from others comparing to traditional face-to-face class, due to lack of facial expressions. Consequently, research should focus on the importance of social presence in online learning, to substitute for direct interaction of face-to-face learning.

Plenty of factors related to the social presence were investigated in prior research. Research looked at social presence when interacting with other human via a medium (such as chats, message boards, or virtual communities), or when interacting with non-human, such as intelligent agent, or simulated parties. Research operationalized these design artifacts via avatar, recommendation agent, emotional or social displays such as pictures and videos (Dormann, 2001; Gefen \& Straub, 2003).

Prior research investigated the impact of social presence on learner satisfaction (Gunawardena \& Zittle, 1997; Rodriguez, 2015; Russo \& Benson, 2005), information satisfaction (Aydingül, Spohrer, Heinzl, \& Kostrzewa, 2016), perceived learning (Richardson \& Swan, 2003), student engagement (Wise, Chang, Duffy, \& Del Valle, 2004), interaction between learners (Lomicka \& lord, 2007), trust (Hess, Fuller \& Campbell, 2009), and attitude toward websites (Daliri, Rezaei \& Ismail, 2014).

\subsection{MOOCs}

Amassive open online course (MOOC) is a course aiming at large-scale interactive participation and open access via the web (Siemens \& Downes, 2013). MOOCs attract learners from different areas, and different cultures and backgrounds. Lucas (2013) argued that MOOCs can potentially disrupt higher education. It connect learners to each other via social engagement tools such as discussion forums to share knowledge, and support online learning (Liyanagunawardena, Adams, \& Williams, 2013).

MOOCs consist lectures, in the form of short videos and related course content, along with feedback mechanisms, in the form of group interaction and collaboration (Alraimi, Zo, and Ciganek, 2015). MOOCs appeared in 2008, and became popular in 2012, thus, it is relatively a new concept that still need much research to understand its ability to transform online learning. Specifically, research need to focus on the design of MOOCs that can make it more accessible by learners. 


\section{Research Model and Hypotheses}

\subsection{Social presence Antecedents}

This research investigated a thorough list of both antecedents and consequences of social presence. Regarding the antecedents, three categories of online community design artifacts were investigated in this study. The first category includes factors related to the MOOC course instructor, self-presentation and extraversion. Second category includes factors related to the members of the online learning community: attention, perceived control over the MOOC website, perceived responsiveness of the MOOC website, and perceived synchronicity of the MOOC website. Third category includes one factor related to the MOOC website itself, media richness. Figure 1 shows the research model

\subsubsection{Self-Presentation}

Ma and Agarwal (2007) defined self-presentation as "a process to communicate one's identity, helping others form a more sophisticated and accurate understanding of (Who am I?)". In traditional face-to-face environments, it is easier to express personality, identity, and social attitudes. Online communities, on the other side, are required to provide some features that assist online users to form online identity, verify this identity, and communicate it to fellow members (Ma and Agarwal, 2007; Blanchard and Markus, 2004). Example of these features are signatures, avatars, and personal pictures. Using such features assist in communicating online behavior along with a complete context.

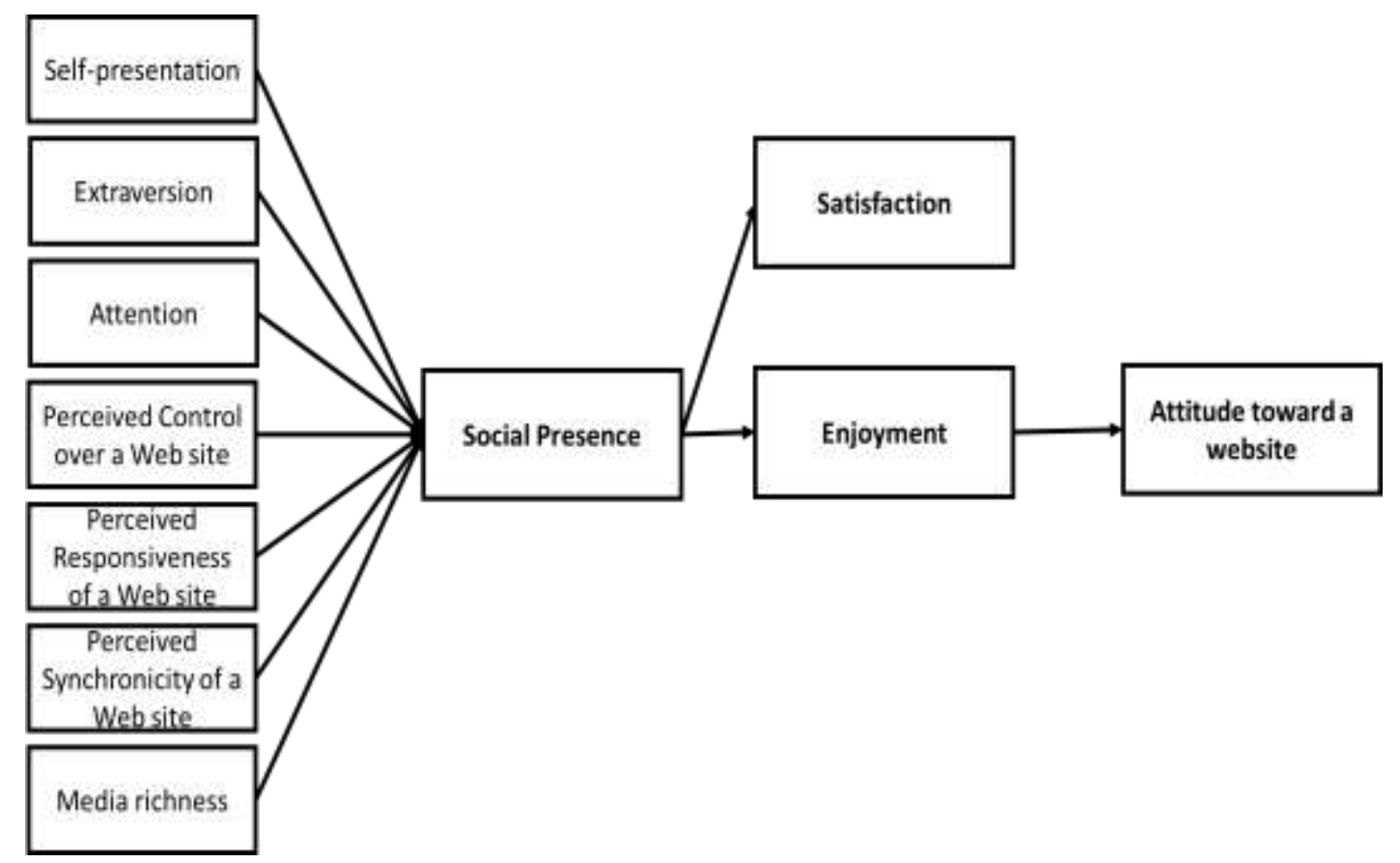

Figure 1. The research model

Shen and Khalifa (2009) found that member's perceived usage of online community artifacts supporting self-presentation is positively related to users' sense of social presence. Prior research also found that online users' self-disclosure positively impact users' engagement in online communities (Imlawi, Gregg, and Karimi, 2015; Imlawi and Gregg, 2014). Experiments found that Facebook users' self-disclosure, such as posting photographs, makes them feel more popular (Christofides, Muise, \& Desmarais, 2009). Therefore, the study hypothesizes:

H1: Self-presentation of MOOC instructor will positively influence students' perceptions of social presence.

\subsubsection{Extraversion}

Prior research on social presence paid an attention to the influence of personality in online settings (Hess, Fuller, and Campbell, 2009). Extraversion is one of the big five personality dimensions (Goldberg, 1981). Isbister and Nass (2000) argued that extraverted personality can be manifested in interfaces through text, voice, and animation.

Social presence theory focused on the human warmth and sociability (Short et al., 1976). Instructors who show 
extraverted personality are expected to be more socially perceived by their students. Therefore, the study hypothesizes:

H2: Extraversion of MOOC instructor will positively influence students' perceptions of social presence.

\subsubsection{Online Learning Members'Attention}

Social presence theory determined the individual differences in the perception of social presence (Short et al., 1976). Users' attention is one of these differences among users. Adding contents to the MOOC website does not mean that every student would pay the same attention, understanding, and acting toward these contents. Consequently, they are not expected to be affected the same way and amount. In their study, Felt et al. (2012) evaluated whether Android users pay attention to the permission information during installing mobile applications. They found that only $17 \%$ of participants paid attention to permissions during installation. According to the Wogalter's Communication-Human Information Processing (C-HIP) model, user attention is the first step between the delivery of online content, such as warnings, and the user's behavior (Smith-Jackson \& Wogalter, 2006). Specifically, attention happens when users notice the online contents.

Prior research investigated many individual differences, such as personal innovativeness (Agarwal \& Prasad, 1998), and computer playfulness (Hess, Fuller, and Campbell, 2009). However, little research studied the influence of attention. Moreover, in prior research there is a confusion between awareness and attention factors. Awareness might happen without noticing any of the interface content, because of prior experiences or knowledge. Attention, howe ver, is the process of noticing interface contents. MOOC students, who pay attention to interface contents, are expected to perceive a higher degree of social presence. Therefore, the study hypothesizes:

H3: MOOC students' attention will positively influence their perceptions of social presence.

\subsubsection{Perceived Control over a MOOC Website}

Cui, Wang, and $\mathrm{Xu}$ (2010) defined website interactivity as "the degree to which the user perceives the Web site to be controllable, responsive, and synchronic". Online users seek to reduce uncertainty in their online experiences. Perceived control over a website assist in reducing the uncertainty (Short et al., 1976).

Cui, Wang, and Xu (2010) found a relationship between perceived control over a website, and the availability of information about fellow users in online community (cognitive social presence). Similarly, they found a relationship between perceived control over a website, and the use of emoticons in online users' comments (affective social presence). Cui, Wang, and Xu (2010) also found that perceived control over a website influence attitude toward a website.

Flow theory stated that when user experience more control on a website, they tend to feel more involvement, more flow, and more pleasure (Ariely, 2000). Thus, it is expected that when users experience more control over a MOOC website, they would perceive a higher degree of social presence. Therefore, the study hypothesizes:

H4: MOOC students' perceived control over a MOOC website will positively influence their perceptions of social presence.

\subsubsection{Perceived Responsiveness of a MOOC Website}

Responsiveness refers to the interactivity between the members of online communities. It was defined by Green and Pearson (2011) as "the presence of feedback to users, and the availability of response from the site managers". E-commerce websites have recognized the importance of website responsiveness. Green and Pearson (2011) found that responsiveness is positively related to perceived ease of use.

Liu (2003) found responsiveness to improve interactivity. When users experience interactive online environment, they are expected to perceive the experience more intimately. Intimacy is one dimension of social presence (Short et al., 1976). People, in face-to-face environment, get a direct response from others. Online environments miss the direct interaction. Therefore, online features, that provide responsive feedbacks, are expected to increase users' feeling of intimacy and sociality.

Online information should be timeliness to be valuable (Doll \& Torkzadeh, 1988). Responsive feedback guarantees a timeliness information, and therefore, it is expected to positively influence online users' perception of social presence, by providing them with high quality information, that decrease their feeling of uncertainty.

Instructor's utilization of conversational method when talking to their students was found to affect the students' perception of social presence (Borup, West, Thomas, and Graham, 2014). A conversational manner needs a responsive behavior from the two parties in an interactive communication. 
Han, Min, and Lee (2015) investigated what characteristics of social network sites fulfill their users' need. They found that immediate feedback, and other intimacy-related characteristics of SNSs, form social presence. Therefore, the study hypothesizes:

H5: Students' perceived responsiveness of a MOOC website will positively influence their perceptions of social presence.

\subsubsection{Perceived Synchronicity of an Online Learning Website}

Liu and Shrum (2002) explained that synchronicity form a powerful basis for website interactivity. They defined synchronicity as the timing of information exchange. A synchronous interaction is an interaction where the exchange between the interaction entities, a website and its users, is concurrent. When the interaction between the online learning website and its members is concurrent, those members are expected to feel more social presence, because concurrency is one of the face-to-face interaction features.

Prior research found a relationship between delay in synchronicity, represented by a longer download time, and negative attitude toward downloaded documents (Sears, Jacko, and Borella; 1997) and attitude toward websites (Dellaert \& Kahn; 1999). Lowry, Romano, Jenkins, and Guthrie (2009) affirmed the positive influence of synchronicity on users' satisfaction. Therefore, the study hypothesizes:

H6: MOOC students' perceived synchronicity of a MOOC website will positively influence their perceptions of social presence.

\subsubsection{Media Richness}

Rich media was defined by Badger, Kaminsky, and Behrend (2014) as those media channels, that can transmit video, and audio, or to enable two-way communication. Hassanein and Head (2007) found that socially rich text and pictures increased perceptions of social presence with online shopping. Rich media deliver a greater feeling of presence (Schmitz \& Fulk, 1991). When the communicated information is complex or ambiguous, then it is more effective to use rich media to convey such information (Badger et al., 2014).

Online learning environments, like MOOCs, are platforms that deliver a high level knowledge. It is more efficient to use richer media channels to convey such a knowledge. According to Adams et al. (1999), the richest interaction is face-to-face interaction, followed by video, audio, and then text. This suggest that rich media is connected to social presence.

Schmitz and Fulk (1991) argued that the ability to convey a sense of personal presence is one dimension that determine the richness of media. Similarly, the availability of two-way communication, which is one dimension of media richness (Badger et al., 2014), is also related to social presence. Therefore, the study hypothesizes:

H7: Media richness of a MOOC website will positively influence students' perceptions of social presence.

\subsection{Social Presence Consequences}

Social presence consequences investigated in this study are students' satisfaction, perceived enjoyment, and their attitude toward the MOOC website.

\subsubsection{Students' Satisfaction}

Sweeney and Ingram (2001, p. 57) defined student satisfaction as "the perception of enjoyment and accomplishment in the learning environment". The influence of social presence on satisfaction is well established in prior research (Rodriguez, 2015). Moore, Masterson, Christophel, and Shea (1996) found that instructor's verbal and nonverbal immediacy behaviors positively influenced students' satisfaction. Gallien and Oomen-Early (2008) noted that students who received consistent personalized instructor feedback, showed more satisfaction. Students' perceptions of social presence positively influenced their overall satisfaction (Russo \& Benson, 2005), their satisfaction with the instructor, and the instructor satisfaction (Richardson \& Swan, 2003). Lack of social presence in online courses was proved to lead to students' dissatisfaction (Cui, Lockee, \& Meng, 2013).

Prior research provided strong evidences regarding the relationship between social presence and students' satisfaction in a text-based medium (Gunawardena and Zittle, 1997), and in the multimedia instruction (Steffey, 2001). Arbaugh (2001) explained that the reason for social presence influence on satisfaction is its ability to reduce the feelings of isolation, and to support the feelings of connection and community.

Richardson and Swan (2003) surveyed students who completed an online learning course. They found students with high overall perceptions of social presence also scored high in terms of perceived learning and perceived satisfaction with the instructor. 
However, there is no consensus among researchers on the relationship between social presence and satisfaction (Rodriguez, 2015). Consequently, more research is still needed to clarify this ambiguity. Most studies found a positive relation between the two factors in online learning environments, however, some studies found a negative relation (So \& Brush, 2008), or no relation between the two factors (Joo, Lim, and Kim, 2011). Therefore, the study hypothesizes:

H8: MOOC students' perceptions of social presence in a MOOC website will positively influence their satisfaction.

\subsubsection{Students' Perceived Enjoyment}

Enjoyment is an intrinsic motivation that was defined by Davis, Bagozzi, and Warshaw (1992) as 'the degree to which performing an activity is perceived as providing pleasure and joy in its own right, aside from performance consequences". It pertains the feeling of joy, fun, and playfulness when committing any activity, regardless any other outcomes or consequences.

In contexts like online learning, enjoyment has emerged as an essential factor. Alraimi et al. (2015) found that perceived enjoyment in learning is one of the most important factors that positively influence students' continuance intention.

Prior research has confirmed the relationship between social presence and enjoyment in many contexts, such as online context (Hassanein \& Head, 2004), mobile multimedia context (Sung \& Yun, 2010), and online shopping context (Koufaris \& Ajit Kambil, 2001). However, there is still little research about the relationship between social presence and enjoyment in other contexts (Hassanein and Head, 2007), especially emerging ones, such as MOOCs. Therefore, the study hypothesizes:

H9: Students' perceptions of social presence in a MOOC website will positively influence their perceived enjoyment.

\subsubsection{Students' Perceived Attitude Toward the MOOC Website}

Attitude expresses the favorable or dis-favorable toward an object. Several studies have investigated the positive influence of enjoyment on attitude towards a website (Hassanein, and Head, 2007; Childers, Carr, Peck, and Carson, 2002; Lee, Cheung \& Chen, 2005; Perea y Monsuwé, Dellaert \& Ruyter, 2004; Van der Heijden, 2003). Therefore, the study hypothesizes:

H10: Students' perceived enjoyment will positively influence their attitude toward the MOOC website.

\section{Method}

This study utilized a Web-based survey to validate the study constructs. Data were collected using a commercially available survey tool; Survey Monkey (www.surveymonkey.com). After the introduction about the study and its objectives, the first part of the survey asked screening questions to determine whether the respondent has participated in any MOOCs courses, and if yes, what MOOCs courses they finished, and which MOOCs websites they frequented. Then, the survey included the measurement items, to measure the proposed study constructs. Items were measured using a seven-points Likert Scale (from 1 - strongly disagree, to 7 strongly agree). The study included eleven constructs which were measured using established questions from previous studies. Final construct's measurement items, along with their sources, are explained in the appendix. Finally, the survey included demographic questions.

A committee of three information systems professors, who have a considerable experience with MOOCs, have reviewed the survey, to make sure that the measurement items are appropriate for the context of the study. They also checked for the clarity of the measurement items, and the wording issues. Finally, the committee have reviewed the revised copy of the survey, to confirm that all their comments, and feedback have been applied, and no further improvements were needed.

The study utilized a convenience sample. The target respondents for this study were students of MOOCs courses. The survey link was posted to MOOCs Facebook groups, similar to other studies that investigated the behavior of online learners (Davis et al., 2014). Facebook was considered relevant to the context of this study, because MOOCs students commonly use Facebook to support their interaction (discussion and collaboration) and engagement (Alraimi et al., 2015; Breslow et al., 2013). Zheng, Han, Rosson \& Carroll (2016) found that students were more engaged in Facebook groups designed for specific MOOCs courses, comparing to the MOOCs discussion forums. Respondents were directed to consider the last MOOCs course they finished when answering the survey. 310 completed responses were collected during two months, from October to December of 2016. 
Control variable considered in this study are gender, experience with MOOCs, and the MOOCs website name and reputation. The study aimed to check if there is a difference between males and females, learners with substantial experience with MOOCs and other with less experience, and users of different MOOCs websites.

\subsection{Data Analysis}

The study used T-Tests to check for the control variables influence. It also used Partial Least Squares (PLS) for the hypotheses testing, and data analysis. PLS was selected because: 1) it can examine paths in the proposed structure model (Sung \& Yun, 2010), 2) it can examine the items of the measurement model (Sung \& Yun, 2010), 3 ) it is more appropriate for predication rather than testing whether data fit a predefined model (Éthier, Hadaya, Talbot, \& Cadieux, 2006), which is consistent with the purpose of this study, and 4) PLS is more appropriate for relatively small sample size (Chin, 1998).

\section{Results}

310 respondents completed the survey. $59.4 \%$ were males. The control variables test showed no impact for gender, and experience with MOOCs, or the MOOCs website name $(\mathrm{P}>0.05)$.

Following Fornell, and Larcker (1981) recommendations, three conditions were checked to evaluate research model properties. First, item loading should be higher than a recommended threshold of 0.7 (Hair, Anderson, Babin, \& Black, 2010). Second, internal consistency should be adequate. For an adequate internal consistency, composite reliability, and Cronbach's $\alpha$ values for each construct should be high, at least 0.7 . Third, the average variance extracted (AVE) should be above 0.5 for each construct. Table 1 demonstrates item loading, composite reliability, Cronbach's $\alpha$, and AVE values for all constructs in the measurement model. All these values were acceptable, comparing to the recommended threshold values.

Discriminant validity was assessed by comparing Square Root of AVE for each construct, with the correlation between this construct and other constructs in the measurement model. Table 2 demonstrates that the study model has a good discriminant validity.

Results from PLS analysis are explained in table 3 and figure 2. All the hypotheses were supported, and significant at $0.05,0.01$, and 0.001 significance levels. The research model explained $63.7 \%$ of the variance for social presence, $32.5 \%$ of the variance for satisfaction, $38.1 \%$ of the variance for enjoyment, and $21.8 \%$ of the variance for attitude toward a website.

Table 1. item loading, composite reliability, Cronbach's $\alpha$, and AVE values

\begin{tabular}{lcccc}
\hline \multicolumn{1}{c}{ Construct } & Items Loading & Composite Reliability & Cronbach's $\alpha$ & AVE \\
\hline Self- Presentation & $(0.7-0.9)$ & 0.91 & 0.78 & 0.71 \\
Extraversion & $(0.7-0.88)$ & 0.79 & 0.84 & 0.65 \\
Attention & $(0.75-0.89)$ & 0.81 & 0.83 & 0.54 \\
Perceived Control & $(0.71-0.73)$ & 0.85 & 0.8 & 0.52 \\
Perceived Responsiveness & $(0.74-0.82)$ & 0.83 & 0.84 & 0.54 \\
Perceived Synchronicity & $(0.71-0.8)$ & 0.86 & 0.85 & 0.59 \\
Media richness & $(0.74-0.75)$ & 0.89 & 0.89 & 0.58 \\
Social presence & $(0.83-0.86)$ & 0.9 & 0.72 & 0.78 \\
Satisfaction & $(0.7-0.82)$ & 0.89 & 0.87 & 0.62 \\
Perceived Enjoyment & $(0.7-.83)$ & 0.77 & 0.78 & 0.58 \\
Attitude toward a website & $(0.7-0.83)$ & 0.77 & 0.57 \\
\hline
\end{tabular}

Table 2. Discriminant validity. Square Root of AVE and inter-construct correlation

\begin{tabular}{|c|c|c|c|c|c|c|c|c|c|c|c|}
\hline & Self.Pres & EV & Attn & PCon & PRes & PSync & MRich & SPres & Sat & PEnj & Attd \\
\hline Self.Pres & 0.84 & & & & & & & & & & \\
\hline EV & 0.44 & 0.81 & & & & & & & & & \\
\hline Attn & 0.34 & 0.32 & 0.73 & & & & & & & & \\
\hline PCon & 0.47 & 0.34 & 0.30 & 0.72 & & & & & & & \\
\hline PRes & 0.30 & 0.33 & 0.35 & 0.35 & 0.73 & & & & & & \\
\hline PSync & 0.48 & 0.36 & 0.36 & 0.49 & 0.48 & 0.77 & & & & & \\
\hline MRich & 0.34 & 0.31 & 0.43 & 0.44 & 0.33 & 0.48 & 0.76 & & & & \\
\hline SPres & 0.40 & 0.44 & 0.49 & 0.45 & 0.52 & 0.40 & 0.40 & 0.88 & & & \\
\hline Sat & 0.35 & 0.35 & 0.39 & 0.51 & 0.39 & 0.45 & 0.36 & 0.38 & 0.79 & & \\
\hline PEnj & 0.31 & 0.44 & 0.34 & 0.42 & 0.52 & 0.46 & 0.43 & 0.42 & 0.38 & 0.76 & \\
\hline Attd & 0.37 & 0.40 & 0.51 & 0.47 & 0.40 & 0.45 & 0.42 & 0.41 & 0.32 & 0.31 & 0.75 \\
\hline
\end{tabular}


Table 3. Hypotheses results

\begin{tabular}{|c|c|c|c|c|}
\hline Hypothesis & $\begin{array}{c}\text { Path } \\
\text { coefficient }\end{array}$ & $\mathrm{t}-$ Value & P-Value & Results \\
\hline 1. Self-Presentation $\rightarrow$ Social Presence & $0.29 * *$ & 3.12 & 0.0005 & Supported \\
\hline 2. Extraversion $\rightarrow$ Social Presence & $0.27 * *$ & 3.07 & 0.0007 & Supported \\
\hline 3. Attention $\rightarrow$ Social Presence & $0.4 * * *$ & 7.65 & 0.0000 & Supported \\
\hline 4. Perceived Control $\rightarrow$ Social Presence & $0.45 * * *$ & 8.21 & 0.0000 & Supported \\
\hline 5. Perceived Responsiveness $\rightarrow$ Social Presence & $0.69 * * *$ & 11.08 & 0.0000 & Supported \\
\hline 6. Perceived Synchronicity $\rightarrow$ Social Presence & $0.59 * * *$ & 10.32 & 0.0000 & Supported \\
\hline 7. Media richness $\rightarrow$ Social Presence & $0.21 *$ & 2.08 & 0.0202 & Supported \\
\hline 8. Social Presence $\rightarrow$ Satisfaction & $0.34 * *$ & 4.02 & 0.0002 & Supported \\
\hline 9. Social Presence $\rightarrow$ Enjoyment & $0.33 * *$ & 3.78 & 0.0002 & Supported \\
\hline 10. Enjoyment $\rightarrow$ Attitude toward a website & $0.2 *$ & 1.98 & 0.021 & Supported \\
\hline
\end{tabular}

Note. Path significances: ${ }^{* * *} \mathrm{p}<0.001 ; * * \mathrm{p}<0.01 ;{ }^{*} \mathrm{p}<0.05$ (Two-tailed test).

\section{Discussion}

\subsection{Key Findings}

This study aimed to provide a more comprehensive understanding of social presence in MOOCs websites, by investigating a thorough list of social presence antecedents and consequences. Specifically, the study investigated the impact of three categories of online community design artifacts on social presence. The first category includes factors related to the course instructor, self-presentation and extraversion. The second category includes factors related to the students in the online learning community, the students' attention, perceived control over the MOOC website, perceived responsiveness of the MOOC website, and perceived synchronicity of the MOOC website. The third category includes one factor related to the MOOC website itself, media richness. The study also investigated the impact of social presence on the students' satisfaction, their perceived enjoyment, and their attitude toward the MOOCs website.

The empirical results significantly support all the hypotheses in the study. In terms of social presence antecedents, results showed that factors belong to the second category; perceived responsiveness $(\beta=0.69, \mathrm{P}<.001)$, perceived synchronicity $(\beta=0.59, \mathrm{P}<.001)$, perceived control $(\beta=0.45, \mathrm{P}<.001)$, and attention $(\beta=0.4, \mathrm{P}$ $<.001)$, are the strongest predictor of social presence.

Results also showed that the list of antecedents investigated by this study explained $63.7 \%$ of the variance for social presence, which is a large share of variance, indicating that the antecedent list considered in this study is well prepared.

\subsection{Implications}

Prior research highlighted the importance of social presence in online environments. However, more investigation on social presence is still needed (Richardson \& Swan, 2003). Similarly, research showed that MOOCs can significantly improve online education. However, there still is more research required, to better understand how to utilize such a technology, to improve online education.

One implication for literature is investigating a thorough list of social presence antecedents and consequences in one model. This provides a better understanding of social presence in online environments, and a better understanding of the interaction effects between these factors. 


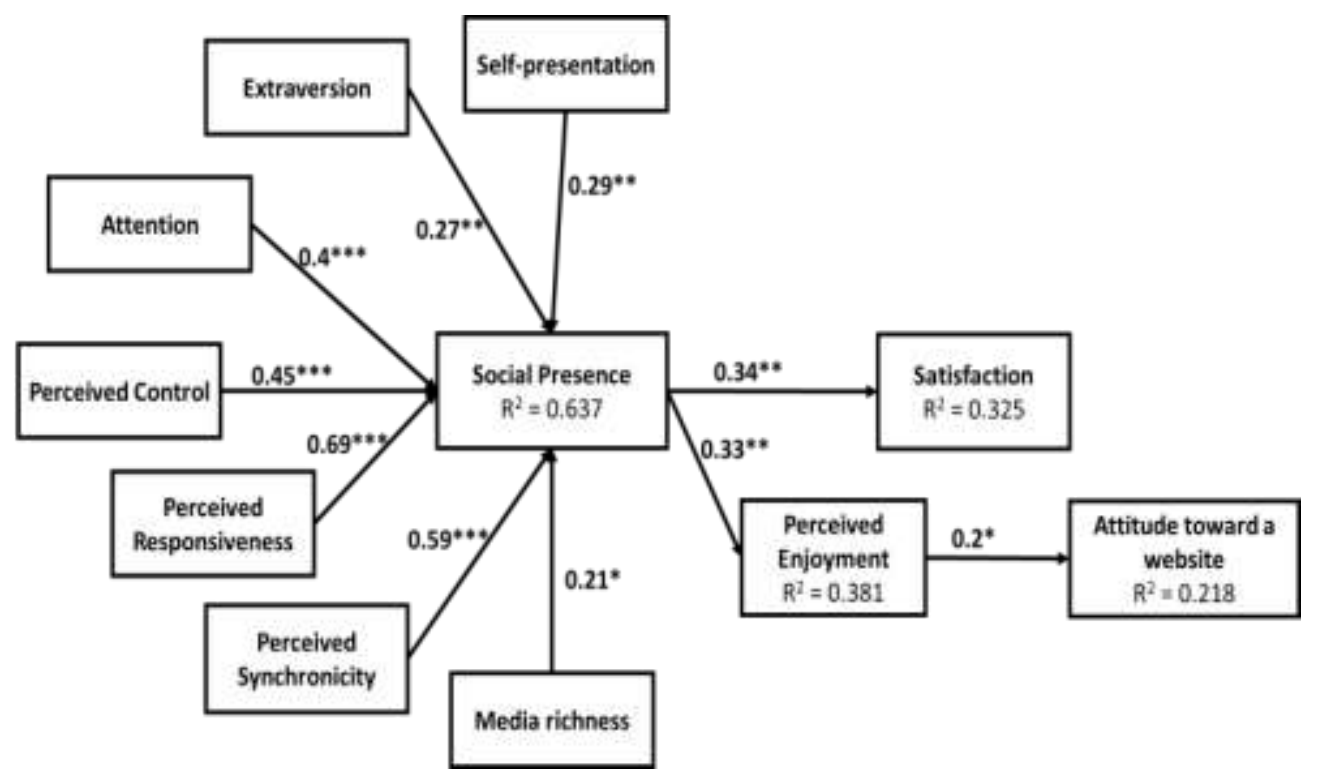

Figure 2. PLS result

This study has offered some contributions for practice as well; it provides MOOCs designers with a thorough list of online community design artifacts that were proven to positively influence social presence in MOOCs websites. The study assist MOOCs designers to focus on the importance of designing interfaces that is more sociable. The study also provides designers with a better understanding of the online users' behavior in MOOCs website.

\subsection{Limitations and Future Research}

Although the study contributed to both theory and practice, there are a few limitations associated with this study. The main limitation of this study came from the convenience sample, utilized by this study, to collect the data. When analyzing data, we found that the most respondents came from top famous MOOCs websites, such as coursera, edX, and Udacity. The name and reputation of such MOOCs websites might affect social presence as well. Future research is recommended to utilize more resources, to reach a diverse sample that includes students from various MOOCs websites.

\section{Conclusions}

This study investigated social presence in MOOCs websites. A thorough list of online community design artifacts was classified into three categories, and their influence on social presence was investigated. Results supported the study hypotheses about the influence of these factors on social presence. The proposed social presence antecedents explained a large share of variance for the social presence (63.7\%).

The study also proved the positive influence of social presence on online users' behavior; namely, students' satisfaction, their enjoyment, and their attitude toward the MOOCs website.

\section{References}

Adams, H. L., Morris, M. G., \& Van Scotter, J. R. (1999). Examining e-mail use in the context of virtual organizations: implications for theory and practice. International Journal of Electronic Commerce, 3(1), 8-26. https://doi.org/10.1080/10864415.1998.11518325

Agarwal, R., \& Prasad, J. (1998). A Conceptual and Operational Definition of Personal Innovativeness in the Domain of Information Technology. Information Systems Research, 9(2), 204-215. https://doi.org/10.1287/isre.9.2.204

Alraimi, K. M., Zo, H., \& Ciganek, A. P. (2015). Understanding the MOOCs continuance: The role of openness and reputation. Computers \& Education, 80, 28-38. https://doi.org/10.1016/j.compedu.2014.08.006

Arbaugh, J. B. (2001). How instructor immediacy behaviors affect student satisfaction and learning in web-based courses. Business Communication Quarterly, 64(4), 42-54. https://doi.org/10.1177/108056990106400405

Ariely, D. (2000). Controlling the Information Flow: Effects on Consumers' Decision Making and Preferences. Journal of Consumer Research, 27(2), 233-248. https://doi.org/10.1086/314322

Aydingül, O., Spohrer, K., Heinzl, A., \& Kostrzewa, M. (2016). Electronic patient briefing and informed consent: 
creating patient trust and information satisfaction through social presence and personalization.

Back, M. D., Schmukle, S. C., \& Egloff, B. (2009). Predicting actual behavior from the explicit and implicit self-concept of personality. Journal of personality and social psychology,97(3), 533. https://doi.org/10.1037/a0016229

Biocca, F., Kim, T., \& Levy, M. R. (1995). The vision of virtual reality. Communication in the age of virtual reality, 3-14.

Blanchard, A. L., \& Markus, M. L. (2004). The experienced sense of a virtual community: Characteristics and processes. ACM Sigmis Database, 35(1), 64-79. https://doi.org/10.1145/968464.968470

Borup, J., West, R. E., Thomas, R., \& Graham, C. R. (2014). Examining the impact of video feedback on instructor social presence in blended courses. The International Review of Research in Open and Distributed Learning, 15(3). https://doi.org/10.19173/irrodl.v15i3.1821

Breslow, L., Pritchard, D. E., DeBoer, J., Stump, G. S., Ho, A. D., \& Seaton, D. T. (2013). Studying learning in the worldwide classroom: Research into edX's first MOOC. Research \& Practice in Assessment, 8, 13-25

Bullen, M. (2007). Participation and critical thinking in online university distance education. International Journal of E-Learning \& Distance Education, 13(2), 1-32.

Cable, D. M. (2006). Managing Job Seekers' Organizational Image Beliefs: The Role of Media Richness and Media Credibility", Journal of Applied Psychology, 91, 828-840. https://doi.org/10.1037/0021-9010.91.4.828

Childers, T. L., Carr, C. L., Peck, J., \& Carson, S. (2002). Hedonic and utilitarian motivations for online retail shopping behavior. Journal of retailing, 77(4), 511-535. https://doi.org/10.1016/S0022-4359(01)00056-2

Chin, W. W. (1998). The partial least squares approach to structural equation modeling. Modern methods for business research, 295(2), 295-336.

Christofides, E., Muise, A., \& Desmarais, S. (2009). Information control and disclosure on Facebook: Are they two sides of the same coin or two different processes. Cyberpsychology and Behavior, 12, 1-5. https://doi.org/10.1089/cpb.2008.0226

Cui, G., Lockee, B., \& Meng, C. (2013). Building modern online social presence: A review of social presence theory and its instructional design implications for future trends. Education and information technologies, 18(4), 661-685. https://doi.org/10.1007/s10639-012-9192-1

Cui, N., Wang, T., \& Xu, S. (2010). The influence of social presence on consumers' perceptions of the interactivity of web sites. Journal of Interactive Advertising, 11(1), 36-49. https://doi.org/10.1080/15252019.2010.10722176

Daliri, E., Rezaei, S., \& Ismail, W. K. W. (2014). Online social shopping: the impact of attitude, customer information quality, effectiveness of information content and perceived social presence. International Journal of Business Environment, 6(4), 426-450. https://doi.org/10.1504/JJBE.2014.064995

Davis, D., Bagozzi, P., \& Warshaw, R. (1992). Extrinsic and intrinsic motivation to use computers in the

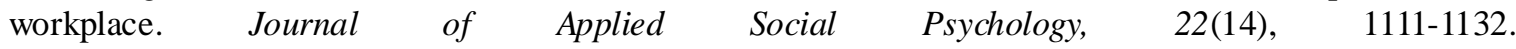
https://doi.org/10.1111/j.1559-1816.1992.tb00945.x

Davis, F. (2004). Improving Computer Skill Training: Behavior Modeling, Symbolic Mental Rehearsal, and the Role of Knowledge Structures. Journal of Applied Psychology, 89, 509-523. https://doi.org/10.1037/0021-9010.89.3.509

Davis, H. C., Dickens, K., Leon Urrutia, M., Vera, S., del Mar, M., \& White, S. (2014). MOOCs for Universities and Learners an analysis of motivating factors.

Dellaert, B. G., \& Kahn, B. E. (1999). How tolerable is delay? Consumers' evaluations of internet web sites after waiting. Journal of interactive marketing, 13(1), 41-54. https://doi.org/10.1002/(SICI)1520-6653(199924)13:1<41::AID-DIR4>3.0.CO;2-S

Deng, L., \& Poole, M. S. (2010). Affect in web interfaces: a study of the impacts of web page visual complexity and order. Mis Quarterly, 711-730. https://doi.org/10.2307/25750702

Doll, W. J., \& Torkzadeh, G. (1988). The measurement of end-user computing satisfaction. MIS Quarterly, 12(2), 259-274. https://doi.org/10.2307/248851

Dormann, C. (2001). Seducing consumers, evaluating emotions. Joint Proceedings of IHM-HCI2001, 2, 10-14. 
Éthier, J., Hadaya, P., Talbot, J., \& Cadieux, J. (2006). B2C web site quality and emotions during online shopping episodes: An empirical study. Information \& Management, 43(5), 627-639. https://doi.org/10.1016/j.im.2006.03.004

Felt, A. P., Ha, E., Egelman, S., Haney, A., Chin, E., \& Wagner, D. (2012). Android permissions: User attention, comprehension, and behavior. In Proceedings of the eighth symposium on usable privacy and security (p. 3). ACM. https://doi.org/10.1145/2335356.2335360

Fornell, C., \& Larcker, D. F. (1981). Evaluating structural equation models with unobservable variables and measurement error. Journal of marketing research, 39-50. https://doi.org/10.2307/3151312

Gallien, T., \& Oomen-Early, J. (2008). Personalized versus collective instructor feedback in the online courseroom: Does type of feedback affect student satisfaction, academic performance and perceived connectedness with the instructor? International Journal on ELearning, 7(3), 463.

Gefen, D., \& Straub, D. W. (2003). Managing user trust in B2C e-services. E-service Journal, 2(2), 7-24. https://doi.org/10.2979/esj.2003.2.2.7

Goldberg, L. R. (1981). Language and individual differences: The search for universals in personality lexicons. Review of personality and social psychology, 2(1), 141-165.

Green, D. T., \& Pearson, J. M. (2011). Integrating website usability with the electronic commerce acceptance model. Behaviour \& Information Technology, 30(2), 181-199. https://doi.org/10.1080/01449291003793785

Gunawardena, C. N., \& Zittle, F. J. (1997). Social presence as a predictor of satisfaction within a computermediated conferencing environment. American journal of distance education, 11(3), 8-26. https://doi.org/10.1080/08923649709526970

Hair, J. F., Anderson, R. E., Babin, B. J., \& Black, W. C. (2010). Multivariate data analysis: A global perspective (Vol. 7): Pearson Upper Saddle River.

Han, S., Min, J., \& Lee, H. (2015). Antecedents of social presence and gratification of social connection needs in SNS: a study of Twitter users and their mobile and non-mobile usage. International Journal of Information Management, 35(4), 459-471. https://doi.org/10.1016/j.ijinfomgt.2015.04.004

Hassanein, K. S., \& Head, M. M. (2004). Building online trust through socially rich web interfaces. In Proceedings of the 2nd Annual Conference on Privacy, Security and Trust, Fredericton, New Bruns wick, Canada (pp. 15-22).

Hassanein, K., \& Head, M. (2007). Manipulating perceived social presence through the web interface and its impact on attitude towards online shopping. Int. J. Human-Comput. Stud., 65(8), 689-708. https://doi.org/10.1016/j.ijhcs.2006.11.018

Hess, T., Fuller, M., \& Campbell, D. (2009). Designing interfaces with social presence: Using vividness and extraversion to create social recommendation agents. Journal of the Association for Information Systems, 10(12), 889. https://doi.org/10.17705/1 jais.00216

Imlawi, J., \& Gregg, D. (2014). Engagement in online social networks: The impact of self-disclosure and humor. International Journal of Human-Computer Interaction, 30(2), 106-125. https://doi.org/10.1080/10447318.2013.839901

Imlawi, J., Gregg, D., \& Karimi, J. (2015). Student engagement in course-based social networks: The impact of instructor credibility and use of communication. Computers \& Education, 88, 84-96. https://doi.org/10.1016/j.compedu.2015.04.015

Isbister, K., \& Nass, C. (2000). Consistency of personality in interactive characters: verbal cues, non-verbal cues, and user characteristics. International journal of human-computer studies,53(2), 251-267. https://doi.org/10.1006/ijhc.2000.0368

Joo, Y. J., Lim, K. Y., \& Kim, E. K. (2011). Online university students' satisfaction and persistence: Examining perceived level of presence, usefulness and ease of use as predictors in a structural model. Computers \& education, 57(2), 1654-1664. https://doi.org/10.1016/j.compedu.2011.02.008

Koufaris, M., \& Ajit Kambil, P. A. L. (2001). Consumer behavior in web-based commerce: an empirical study. International Journal of Electronic Commerce, 6(2), 115-138. https://doi.org/10.1080/10864415.2001.11044233

Kumar, N., \& Benbasat, I. (2006). Research note: the influence of recommendations and consumer reviews on 
evaluations of websites. Information Systems Research, 17(4), 425-439.

https://doi.org/10.1287/isre.1060.0107

Lee, M. K., Cheung, C. M., \& Chen, Z. (2005). Acceptance of Internet-based learning medium: the role of extrinsic and intrinsic motivation. Information \& management, 42(8), 1095-1104. https://doi.org/10.1016/j.im.2003.10.007

Liu, Y. (2003). Developing a scale to measure the interactivity of websites. Journal of advertising research, 43(02), 207-216. https://doi.org/10.2501/JAR-43-2-207-216

Liu, Y., \& Shrum, L. J. (2002). What is interactivity and is it always such a good thing? Implications of definition, person, and situation for the influence of interactivity on advertising effectiveness. Journal of advertising, 31(4), 53-64. https://doi.org/10.1080/00913367.2002.10673685

Liyanagunawardena, T. R., Adams, A. A., \& Williams, S. A. (2013). MOOCs: A systematic study of the published literature 2008-2012. The International Review of Research in Open and Distributed Learning, 14(3), 202-227. https://doi.org/10.19173/irrodl.v14i3.1455

Lomicka, L., \& Lord, G. (2007). Social presence in virtual communities of foreign language (FL) teachers. System, 35(2), 208-228. https://doi.org/10.1016/j.system.2006.11.002

Lowry, P. B., Romano, N. C., Jenkins, J. L., \& Guthrie, R. W. (2009). The CMC interactivity model: How interactivity enhances communication quality and process satisfaction in lean-media groups. Journal of Management Information Systems, 26(1), 155-196. https://doi.org/10.2753/MIS0742-1222260107

Lucas Jr, H. C. (2013). Can the Current Model of Higher Education Survive MOOCs and Online Learning? Educause Review, 48(5), 54.

M. Badger, J., E. Kaminsky, S., \& S. Behrend, T. (2014). Media richness and information acquisition in internet recruitment. Journal of Managerial Psychology, 29(7), 866-883. https://doi.org/10.1108/JMP-05-2012-0155

Ma, M., \& Agarwal, R. (2007). Through a glass darkly: Information technology desi gn, identity verification, and knowledge contribution in online communities. Information systems research, 18(1), 42-67. https://doi.org/10.1287/isre.1070.0113

Miranda, S. M., \& Saunders, C. S. (2003). The social construction of meaning: An alternative perspective on information sharing. Information systems research, 14(1), 87-106. https://doi.org/10.1287/isre.14.1.87.14765

Moore, A., Masterson, J. T., Christophel, D. M., \& Shea, K. A. (1996). College teacher immediacy and student ratings of instruction. Communication Education, 45(1), 29-39. https://doi.org/10.1080/03634529609379030

Nadkarni, S., \& Gupta, R. (2007). A task-based model of perceived website complexity. Mis Quarterly, 501-524. https://doi.org/10.2307/25148805

Perea y Monsuwé, T., Dellaert, B. G., \& De Ruyter, K. (2004). What drives consumers to shop online? A literature review. International journal of service industry management, 15(1), 102-121. https://doi.org/10.1108/09564230410523358

Qiu, L., \& Benbasat, I. (2005). An investigation into the effects of Text-To-Speech voice and 3D avatars on the perception of presence and flow of live help in electronic commerce. ACM Transactions on Computer-Human Interaction (TOCHI), 12(4), 329-355. https://doi.org/10.1145/1121112.1121113

Richardson, J., \& Swan, K. (2003). Examing social presence in online courses in relation to students' perceived learning and satisfaction.

Riva, G., Davide, F., \& IJsselsteijn, W. A. (2003). Being there: The experience of presence in mediated environments. Being there: Concepts, effects and measurement of user presence in synthetic environments, 5.

Rodriguez, M. (2015). The Relationship Between Social Presence, Student Satisfaction and Academic Achievement in Fully Online Asynchronous Courses (Doctoral dissertation).

Russo, T., \& Benson, S. (2005). Learning with invisible others: perceptions of online presence and their relationship to cognitive and affective learning. Educational Technology \& Society, 8(1), 54-62.

Schmitz, J., \& Fulk, J. (1991). Organizational colleagues, media richness, and electronic mail: a test of the social influence model of technology use. Communication Research, 18(4), 487-523. 
https://doi.org/10.1177/009365091018004003

Sears, A., Jacko, J. A., \& Borella, M. S. (1997). Internet delay effects: how users perceive quality, organization, and ease of use of information. In CHI'97 Extended Abstracts on Human Factors in Computing Systems (pp. 353-354). ACM. https://doi.org/10.1145/1120212.1120430

Shen, K. N., \& Khalifa, M. (2009). Design for social presence in online communities: A multidimensional approach.

Short, J., Williams, E., \& Christie, B. (1976). The social psychology of telecommunications.

Siemens, C. G., \& Downes, S. (2013). What is a MOOC?

Smith-Jackson, T. L., \& Wogalter, M. S. (2006). Methods and procedures in warning research. Handbook of warnings, 23-33.

So, H. J., \& Brush, T. A. (2008). Student perceptions of collaborative learning, social presence and satisfaction in a blended learning environment: Relationships and critical factors. Computers \& Education, 51(1), 318-336. https://doi.org/10.1016/j.compedu.2007.05.009

Steffey, C. S. (2001). The effects of visual and verbal cues in multimedia instruction (Doctoral dissertation, Virginia Polytechnic Institute and State University).

Sung, J., \& Yun, Y. (2010). Toward a more robust usability concept with perceived enjoyment in the context of mobile multimedia service. International Journal of Human Computer Interaction, 1(2), 12-32.

Sweeney, J., \& Ingram, D. (2001). A comparison of traditional and web-based tutorials in marketing education: An exploratory study. Journal of Marketing Education, 23(1), 55-62. https://doi.org/10.1177/0273475301231007

Van der Heijden, H. (2003). Factors influencing the usage of websites: the case of a generic portal in The Netherlands. Information \& management, 40(6), 541-549. https://doi.org/10.1016/S0378-7206(02)00079-4

Voss, B. D. (2013). Massive open online courses (MOOCs): A primer for university and college board members. AGB Association of Governing Boards of Universities and Colleges.

Ward, M., \& Newlands, D. (1998). Use of the Web in undergraduate teaching. Computers \& Education, 31(2), 171-184. https://doi.org/10.1016/S0360-1315(98)00024-4

Wise, A., Chang, J., Duffy, T., \& Del Valle, R. (2004). The effects of teacher social presence on student satisfaction, engagement, and learning. Journal of Educational Computing Research, 31(3), 247-271. https://doi.org/10.2190/V0LB-1M37-RNR8-Y2U1

Yu, J., Ha, I., Choi, M., \& Rho, J. (2005). Extending the TAM for a t-commerce. Information \& management, 42(7), 965-976. https://doi.org/10.1016/j.im.2004.11.001

Zheng, S., Han, K., Rosson, M. B., \& Carroll, J. M. (2016). The role of social media in MOOCs: how to use social media to enhance student retention. In Proceedings of the Third (2016) ACM Conference on Learning@ Scale (pp. 419-428). ACM. https://doi.org/10.1145/2876034.2876047 


\section{Appendix}

\section{Measurement and items}

Table A1. Measurement and items

\begin{tabular}{|c|c|c|}
\hline Construct & Items & Source \\
\hline Self-presentation & $\begin{array}{l}\text { 1. I tell my stories to other community members in this community. } \\
\text { 2. I share my photos or other personal information with people from } \\
\text { this community. } \\
\text { 3. I express my opinions in my posts. } \\
\text { 4. I present information about myself in my profile. } \\
\text { 5. I use a special (or meaningful) signature in this community that } \\
\text { differentiates me from others. } \\
\text { 6. I use a special (meaningful) name or nickname in this community } \\
\text { that differentiates me from others. } \\
\text { 7. I let other community members visit my personal Web page. }\end{array}$ & $\begin{array}{l}\text { Ma and Agarwal } \\
\text { (2007) }\end{array}$ \\
\hline Extraversion & $\begin{array}{ll}\text { Please indicate the extent to which the following attributes apply to you: } \\
\text { 1. } & \text { Sociable. } \\
\text { 2. } & \text { Talkative. } \\
\text { 3. } & \text { Active. } \\
\text { 4. } & \text { Impulsive } \\
\text { 5. } & \text { Outgoing } \\
\text { 6. } & \text { Shy } \\
\text { 7. } & \text { Reticent } \\
\text { 8. } & \text { Passive } \\
\text { 9. } & \text { Deliberate } \\
\text { 10. } & \text { Reserved }\end{array}$ & $\begin{array}{l}\text { Back, Schmukle, } \\
\text { and Egloff (2009) }\end{array}$ \\
\hline Attention & $\begin{array}{l}\text { 1. I paid close attention to the community interaction. } \\
\text { 2. I was able to concentrate on the community interaction } \\
\text { 3. The community interaction held my attention. } \\
\text { 4. During my interaction in this community, I was absorbed by the } \\
\text { demonstrated activities. }\end{array}$ & Davis (2004) \\
\hline $\begin{array}{l}\text { Perceived Control over a } \\
\text { Web site }\end{array}$ & $\begin{array}{l}\text { 1. While I was on the site, I was always aware where I was. } \\
\text { 2. While I was on the site, I always knew where I was going. } \\
\text { 3. I was delighted to be able to choose which link and when click. } \\
\text { 4. I feel that I have a great deal of control over my visiting } \\
\text { experience at this site. } \\
\text { 5. While I was on the Web site, I could choose freely what I wanted } \\
\text { to see. }\end{array}$ & $\begin{array}{c}\text { Cui, Wang, and } \mathrm{Xu} \\
\text { (2010) }\end{array}$ \\
\hline $\begin{array}{c}\text { Perceived } \\
\text { Responsiveness }\end{array}$ & $\begin{array}{l}\text { 1. The Web site is effective in gathering visitors' feedback. } \\
\text { 2. This Web site facilitates two-way communication between the } \\
\text { visitors and the site. } \\
\text { 3. The Web site makes me feel it wants to listen to its visitors. } \\
\text { 4. The Web site gives visitors the opportunity to talk back. }\end{array}$ & $\begin{array}{l}\text { Cui, Wang, and Xu } \\
\text { (2010) }\end{array}$ \\
\hline $\begin{array}{c}\text { Perceived Synchronicity } \\
\text { of a Web site }\end{array}$ & $\begin{array}{l}\text { 1. The Web site processed my input very quickly. } \\
\text { 2. Getting information from the Web site is very fast. } \\
\text { 3. I was able to obtain the information I wanted without any delay. } \\
\text { 4. When I clicked on the links, I felt I was getting instantaneous } \\
\text { information. }\end{array}$ & $\begin{array}{l}\text { Lowry, Romano, } \\
\text { Jenkins, and } \\
\text { Guthrie (2009) }\end{array}$ \\
\hline Media richness & $\begin{array}{l}\text { 1. This Web site give and receive timely feedback. } \\
\text { 2. This Web site use rich and varied language. } \\
\text { 3. This Web site communicate a variety of different cues (such as } \\
\text { emotional tone or attitude) }\end{array}$ & Cable (2006) \\
\hline Social Presence & $\begin{array}{l}\text { 1. There is a sense of human contact in the website. } \\
\text { 2. There is a sense of personalness in the website. } \\
\text { 3. There is a sense of sociability in the website. } \\
\text { 4. There is a sense of human warmth in the website. } \\
\text { 5. There is a sense of human sensitivity in the website. }\end{array}$ & $\begin{array}{c}\text { Kumar, and } \\
\text { Benbasat (2006) }\end{array}$ \\
\hline Satisfaction & $\begin{array}{l}\text { 1. After using this website, I am: very dissatisfied - very satisfied. } \\
\text { 2. After using this website, I am: very displeased - very pleased. } \\
\text { 3. Using this website made me: frustrated - contented. } \\
\text { 4. After using this website, I feel: terrible - delighted. } \\
\text { 5. After using this website, I will: never recommend it to my friends } \\
\text { - strongly recommend it to my friends. } \\
\text { 6. After using this website, I will: never use it aga in - most likely use } \\
\text { it again. }\end{array}$ & $\begin{array}{l}\text { Nadkarni, and } \\
\text { Gupta (2007) }\end{array}$ \\
\hline Perceived Enjoyment & $\begin{array}{l}\text { 1. I found using this website entertaining } \\
\text { 2. I found using this website pleasant }\end{array}$ & $\begin{array}{l}\text { Yu, Ha, Choi, and } \\
\text { Rho (2005) }\end{array}$ \\
\hline
\end{tabular}


3. I found using this website is exciting

4. I found using this website is fun

5. I found using this website is enjoyable.

Attitude toward a

1. I would enjoy visiting this website.

website

2. I like to spend much time browsing this website.

Deng and Poole

3. I would try to leave this website as soon as possible.

(2010)

4. I would avoid getting back to this website after I have left it.

5. I want to avoid exploring or investigating this website

6. I like this website.

7. I would avoid any unplanned activity in this website.

8. I would be satisfied with this website.

9. I would have a positive attitude toward this website.

\section{Copyrights}

Copyright for this article is retained by the author(s), with first publication rights granted to the journal.

This is an open-access article distributed under the terms and conditions of the Creative Commons Attribution license (http://creativecommons.org/licenses/by/4.0/). 